\title{
The Existence of the Statement of the Companions (Fatwā Sahāba) and Its Hujjah in Islamic Legal Thoughts
}

\author{
Hamid Pongoliu \\ Institut Agama Islam Negeri Sultan Amal, Gorontalo - Indonesia \\ e-mail: pongoliuhamid@iaingorontalo.ac.id
}

\begin{abstract}
Fatwā șahāba can be used as hujjah (proof) even though the ulama (scholars) have different opinions regarding its validity. The ulama categorize the Companions' fatwa as one of the sources of law decision which is still being disputed about the validity. It is different from the Qur'an, Sunnah, Ijmā', and Qiyās that have been agreed by the most of the scholars as a source of Islamic law. The Companions' fatwa has an influence on the development of Islamic law thought which can be substantially equated like a figh, because it is the result of istinbät (efforts to extract the zannī (speculative) sharia law from original sources through the mobilization of all natural reasoning abilities) and the results of the Companions ra'y (establish a law of contemporary problems that have not been found in the Qur'an and hadith) which have been codified according to the particular mazhab. Therefore, the Companions fatwo $\bar{a}$ is the result of the ijtihad of the Companions as ulama of the previous generation and became the hujjah of the ulama until today who have colored Islamic law thought, such as fatwā of Abū Bakr, Umar, 'Uthmān, 'Alī, 'Abdullāh Ibn 'Abbās, 'Abdullāh Ibn Mas'ūd and other Companions. At least the fatwō șahaba can be used as hujjah in istinbāt of islamic law when new problems arise, and no proposition is found in the Qur'an and hadith.
\end{abstract}

Keyword: eksistence; fatwā șahāba; hujjah; development of Islamic legal thought

Fatwā sahabat dapat dijadikan huijah walaupun para ulama berbeda pendapat mengenai keabsahannya. Ulama mengategorikan fatwō sahabat sebagai salah satu sumber pengambilan hukum yang masih dipertentangkan keabsahannya. Berbeda dengan al-Qur'an, sunnah, ijmak dan qiyās yang telah disepakati oleh jumhur ulama sebagai sumber hukum Islam. Fatwō sahabat memberikan pengaruh terhadap perkembangan pemikiran hukum Islam yang secara substansial dapat disamakan seperti layaknya fikih. Sebab fatwā sahabat adalah hasil istinbāt hukum yang digali dari dalil-dalil nașs yang zannī dan hasil ra'y sahabat dari masalah-masalah yang tidak terdapat dalilnya dalam al-Qur'an dan hadis yang telah dikodifikasikan menurut mazhab tertentu. Karena itu, fatwā sahabat merupakan hasil ijtihad sahabat sebagai ulama generasi sesudah Nabi saw. dan menjadi hujjah bagi para ulama sampai zaman sekarang yang telah mewarnai pemikiran hukum İlam, seperti fatwā Abū bakar, 'Umar, 'Uthmān, 'Alī, 'Abdullāh bin 'Abbās, 'Abdullāh bin Mas'ūd dan sahabat-sahabat lainnya. Setidaknya fatwō sahabat dapat dijadikan hujjah dalam istinbāt hukum Islam, ketika muncul masalah-masalah baru dan tidak ditemukan dalil ayat maupun hadis.

Keyword: eksistensi; fatwā sahabat; hujjah; perkembangan pemikiran hukum Islam 


\section{Introduction}

Fatwa Sahāba (the statement of the companions) is the result of the thought of the sahāaba in the ijtihad to establish the law of cases that are not contained in the Qur'an and the traditions of the Prophet. The statement of the companions in Islamic legal thinking can be used as a proof, because a companion is a person who can be accepted by the news in establishing the law. Companions are people who meet and can know and understand the actions of the Messenger of Allah during the enactment of the law. ${ }^{1}$ Establishment of the law preceded by events or questions of the people who were witnessed directly by the companions who were constantly accompanying the Prophet. The companions who were always with the Prophet were Khulafā' al-Rāshidīn, 'Abdullāh ibn 'Abbās, 'Abdullāh ibn Mas'ūd, Anas bin Mālik, Zayd bin Thābit, 'A'isha, Umm Salāmah and the wives of the Prophet, Abū Hurayrah, 'Abdullāh ibn 'Umar, Mu'adh ibn Jabbāl, and Abū Mūsā al-Ash'ārī and other companions. Companions are people who are more aware of the tashri process so that they too know the method followed by the Prophet when an event was confronted with him. ${ }^{2}$

Companions are those who believe in the Prophet, associate with him for a long time and die in an Islamic state. Al-Baqilani and several other scholars, such as Ibn Faruk and Ibn Sam'an, stated that the Companions were people who had long been associated with the Prophet and learned a lot from the Prophet by following and taking his teachings. ${ }^{3}$ When faced with a new problem, they identify by looking at the text of the Koran to find out if the new problem is contained in it, if no verses are found relating to the problem that arises, they see the hadith, if not found in the hadith they ask for information from other șahāba, did they hear anything from the Prophet regarding the problem he was facing. This is like when Abu Bakr was asked about the grandmother's inheritance part. First, he looked for verses of the Qur'an relating to the matter of inheritance, then he gathered the companions to be

\footnotetext{
${ }^{1}$ Rasyad Hasan Khalil, Tarikh Tasyri': Sejarah Lagalisasi Hukum Islam, ed. Nadirsyah Hawari (Amzah, 2009), 58.

${ }^{2}$ Rasyad Hasan Khalil, Tarikh Tasyri': Sejarah Lagalisasi Hukum Islam, 78; Nurdin Juddah, 'Metode Ijtihad Hakim dalam Penyelesaian Perkaran: Studi Kasus di Pengadilan Tinggi Agama Makassar Sulawesi Selatan' (UIN Alauddin Makasar, 2010), 32.
}

${ }^{3}$ M. Sulaymān ‘Abdullāh Al-Asqar, Al-Wādịh Fị Ușūl Al-Fiquh (Dār al-Nafāiss, 2001), 131. 
asked for information on whether there was a history of the Prophet about the inheritance of the grandmother. ${ }^{4}$

Then al-Mughīrah testified that the Prophet gave him one-sixth. His statement was strengthened by the statement of Muhammad ibn Maslamah after that Abū Bakr set 1/6 for the grandmother. The Companions never innovate in matters relating to religion, if they did not have the theological foundation that contained them, either from the Qur'an or from the Prophet's hadith. New problems that emerge as a logical consequence of the sociocultural and socio-political development of the people which are very dynamic due to the increasing breadth of Islam and the changing circumstances surrounding them and not all problems have a clue based on the Koran and the hadith of the Holy Prophet, in fact many of them are truly new and do not have religious practical instructions. ${ }^{5}$ The Companions acted as mujtahids explaining the positions of the texts and connecting with each other and giving fatwās in matters not in the texts. It is they who act as legislative bodies and they also get that right not through election, but solely because of their expertise and skills.

The sources or propositions of Islamic law that are used in the time of companions are the Qur'an, hadith and ijtihad (ra'y). ${ }^{6}$ Ijtihad is done by șahāba in the form of a collective, sahāba gather and deliberate on the law of a case. The results of a sahāba's discussion is called ijmā'. Even though the Companions held deliberations but between them there were still differences in the legal status caused by the nature of the Qur'an and hadith as well as differences in ra'y in addition to socio-culture which clearly influenced. This paper seeks to examine some of the issues surrounding the existence of the fatwā of șahāaba and their validity as a source of law disputed by the scholars.

\section{Fatwā Șaḥāba in the Development of Islamic Legal Thought}

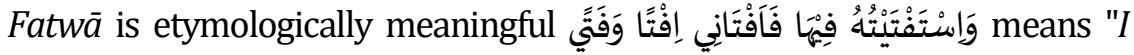
asked him for a fatwā on the matter, and he gave me a fatwä".7 Whereas in terminology, fatwa means the explanation of sharia law over a problem from existing problems, which are supported by propositions derived from the

\footnotetext{
4Madhī Faḍlullāh, Al-Ijtihād Wa Al-Manțiq Al-Fiqh Fì Al-Islām (Beirut: Dār al-Ṭalīah, 1987), 45; Ahmad Ibrāhīm Bik, Tārīkh Al-Tashrī Al-Islāmī (Kairo: Dār al-Anșār, n.d.), 23.

5Jalāl al-Dīn 'Abd al-Rahmān Al-Suyūṭī, Al-Radd 'alā Man Akhlad Ilā Al-Arḍ Wa Jahila Ann Al--jtihāed Fi Kulli 'Așr Farḍ (Beirut: Dār al-Kutub al-'Ilmiyah, 1983), 67.

6Jaih Mubarok, Sejarah dan Perkenbangan Hukun Islam (Bandung: Remaja Rosda Karya, n.d.), 23.

${ }^{7}$ HLM. A. Achyar Aminudin Khairul Umam, Ushul Fiqh II (Bandung: Pustaka Setia, 1989, 173).
} 
Qur'an, sunnah, and ijtihad. Fatwā is a matter that is very urgent for humans, because not everyone is able to explore the shari'ah laws. As for ijtihad, according to al-Âmidī, it means:

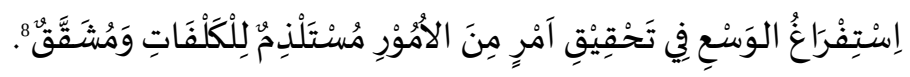

Meaning: "Describe all abilities in researching and studying a case that necessitates difficulties and difficulties".

Based on the explanation above, it was concluded that the fatwo was an explanation of sharia law on various kinds of problems that occurred in the midst of the community. If a fatwa is an explanation of sharia law on a particular issue, then the rules for taking a fatwo are not the same as the rules of ijtihad. Thus, a mufti is the same as mujtahìd.

Ijtihad is interpreted as: 9

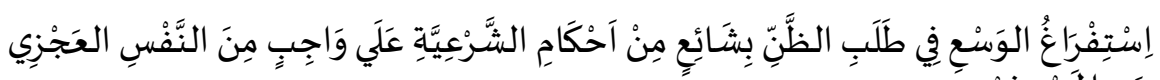

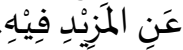

Meaning: "Pouring out all his ability to explore the laws of syara from the postulates of zanni, until he felt unable to make more effort than he had poured out".

Based on the above definition it can be understood that fatwa is the result of ijtihad of the muftiss or mujahids. Fatwā is a process of ijtihad which is carried out by digging sharia law from the arguments that are zannī by devoting all their energy and abilities so that it is no longer possible for him to make more effort.

Fatwās are recognized as ijtihad if they meet the following three conditions: ${ }^{10}$

1) Muftī in ijtihad is only on the arguments of zannī. This is because according to al-Âmidī, the qaț'i (certain) laws are not explored based on the ijtihad process. The law contained in the texts of the qați does not require any other interpretation. There is no contradiction or multi-interpretation of the texts of the qațî. On this basis, ijtihad does not apply to matters of

8‘Alī lbn-Abī 'Alī Al-Āmidī, Al-Iḥkām Fĩ Ușūl Al-Ahkām, II. (Beirut: Dār al-Kitāb al-'Arabī, 1984), 250.

${ }^{9}$ Satria Effendi, Ushul Fiqh, ed. M. Nurul Irfan Aminuddin Ya'kub (Jakarta: Kencana Prenada Media Group, 2008), 245.

10HLM. A. Achyar Aminudin Khairul Umam, Ushul Fiqh II,140-141. 
faith, nor the laws of sharia which the appointment is certain. For example the punishment of cutting off hands for thieves, hadd for adulterers, killing for apostates and so forth.

2) Muftì in ijtihad do the process of extracting sharia law, not the process for things that can be understood directly by reason, or cases that can be sensed. Research and trials in the laboratory to produce a hypothesis is not called ijtihad

3) A muftī in doing ijtihad must seriously by exerting the peak of his energy and abilities, to the extent that he cannot possibly make more effort than he has done. A muftĩ is not said to be doing ijtihad if he only devotes some of his abilities and energy, even though he is still able to make more effort than he has done.

Sahāāba, as stated by the ulama of ușūl, give indications to șahāba or people who can be accepted by the news in establishing the law. this is because it is impossible for someone who only met briefly to know and understand how the actions of the Prophet. during the tashrì' process. In addition, many legal provisions are preceded by events or questions, so that people who witness directly can understand the legal status of the event. Among the companions of the Apostle who accompanied him continuously were al-Khulafā' al-Rāshidīn, 'Abdullāh Ibn Mas'ūd, Anas bin Mālik, Zayd bin Thābit, 'Aisha, Umm Salāmah and the Apostles' wives, Abū Hurayrah, 'Abdullāh Ibn 'Umar, Mu'ādh Ibn Jabbāl, and Abū Mūsā al-Ash'arī. As a person who is close to the Apostle, a companion is someone who knows more about the tashrī process so that they also know how the method or method adopted by the Prophet when an event is presented to him. The lesson they received from the Prophet was to formulate a legal problem that came after the Prophet's death. The steps of the companion have an important role for the next legal determination. They help the people in understanding the Qur'an and the Sunnah. The method of istinbat used by șahāba is a model of ijtihad.

As for the terminology, the scholars differed in defining șahāba. According to the hadith scholars, a companion is a person who meets with the Prophet, believes in him, and dies in Islam. ${ }^{11}$ This definition gives an understanding that (1) Companions are people who meet with the Prophet, absolutely, whether

11'Abd Al-'Azīz, 'Al-Șahābī', in Al-Mawsū'oh Al-Islāmiyah Al-'Ammah (Kairo: Majlis A'lā, 2003), 846; 'Alī Jum’ah, Qawl Al-Ṣaḥāīī inda Ușūliyyīn (Kairo: Dār al-Risālah, 2004), 9. 
they meet only once or often, for a long time or for a while. (2) A person who meets with the Prophet, after he has been sent as an Apostle. (3) Someone who is a contemporary of the Prophet, but does not meet him, is not called a șahāba but a mukhadharam. Sahāāba, according to the ulama of ușūl, are all people who believe in the Prophet, associate with him for a long time, and die in an Islamic state. Meanwhile, according to al-Baqilani, Ibn Faruk, and Ibn Sam'an, a conpanion is a person who socialized in a long time and studied with the Prophet by following him and taking lessons from him..$^{12}$

Some of the definitions above explain that there are slight differences in defining sahāaba. However, all agreed that the Companions were people who believed in the Prophet and died in an Islamic state. The difference lies in whether or not the meeting with the Prophet. The scholars of hadith do not require the necessity of frequently meeting the Prophet, but only once is enough. This is because they consider that the Companions are hadith narrators and do not demand that they frequently meet and associate with the Prophet. Therefore, the Companions differ in quantity in narrating the hadith. Whereas the ulama of ușūl required the duration of association because they considered that they were the generation that would convey Islamic laws and this required a long association with the Prophet so that they could produce knowledge and deep understanding.

\section{The Influence of Fatwā Șahāba Against Islamic Legal Thought}

The death of the Holy Prophet, certainly had a great influence. Even 'Umar Ibn Khatțāb came to say "whoever says Muhammad is dead, I will kill". Abū Bakr later confirmed that the Prophet. has really died. In this case, he based on Surah Āli 'Imrān Verse 144. This attitude of Abū Bakr was considered the first ijtihad after the Prophet died. 13

The task of the Companions became difficult after the Prophet's death was caused by;

1) At the time when the Prophet was alive, Islamic law in the aspect of law was applied as community law. This is because the Holy Prophet had two authorities at once, religious and

12M. Sulaymān 'Abdullāh Al-Asqar, Al-Wāḍịh Fĩ Ușūl Al-Fiqh, 131.

13Bozena Gajane Strzyzewska, Tārīkh Al-Tashrī Al-Islāmī (Beirut: Dār al-Awqāf al-Jadīdah, 1980), 39. 
political power. This situation is certainly still held tight by them. ${ }^{14}$

2) Their attitude to not do something that was never exemplified by the Holy Prophet, such as the attitude of Abu Bakr when given advice about the need to collect al-Qur'an in one manuscripts "kayf naf'al shay' lam yaf'alhu Rasūlallāh". ${ }^{15}$

3) Internal encouragement to carry out and guard the purity of Islamic teachings as the main task of replacing the Messenger of Allah.

4) External factors such as the emergence of new problems that demand responses and solutions that have a theological foundation.

The behavior and deeds of the Companions will not be found without the basis of the Qur'an and sunnah. ${ }^{16}$ Sahâa ba never innovate in matters relating to religious matters, if they do not have a theological foundation that holds them back. Meanwhile, new problems must emerge as a logical consequence of socio-cultural and socio-political developments due to the wider expansion of Islam and the changing circumstances surrounding it. Not all of these problems have a precedent from the hadith of the Prophet, in fact many of them are truly new that do not have practical religious instructions.

Islamic teachings that originate from the Qur'an and hadith have been believed to guide every human behavior. ${ }^{17}$ On this basis the Prophet's companions had no choice but to commit ijtihad. Therefore, also the scholars agree that the law of ijtihad is fard kifäyah which means to forbid the absence of a period of ijtihad activities. Indeed, when the Prophet was still alive, if there were problems, the Companions could directly ask him or if the Prophet's position was far away, they made their own pilgrimage and then conveyed the results of their ijtihad to the Prophet. All matters became clear, whether confirmed or corrected by the Holy Prophet. ${ }^{18}$

\footnotetext{
37.

${ }^{14}$ Muhammad Zuhri, Hukum Islam dalam Lintasan Sejarah (Jakarta: Remaja Rosda Karya, 1996),

15Muhammad Ibn Ismāîl Al-Bukhārī, Șaḥịh Al-Bukhārī, III. (Beirut: Dār al-Ṣa’’b, n.d.), 175.

16Muhammad 'AlīAl-Sāyis, Tārīkh Al-Fiqh Al-Islāmiyah, 52.

${ }^{17}$ Al-Suyūțī, Al-Radd 'alā Man Akhlad Ilā Al-Arḍ Wa Jahila Ann Al-Ijtihād Fi Kulli 'Așr Fard, 67.

18Muhammad Mūsā Tuwānā, Al-Ijtihād Wa Madā Hājātinā Ilayh Fī Hādhā Al-'Așr (Kairo: Dār alKutub al-Hadīthah, n.d.), 37.
} 
Although the Holy Prophet had tashrī' authority, he never forbade his companions from performing jihad. In fact, the Holy Prophet appreciated the action. ${ }^{19}$ That proves that the Prophet legitimized the actions of his companions in the pilgrimage. But after the Prophet's death, there was no such authority anymore. So that what is done by the successors of the Prophet's leadership is only looking for a basis for solving any problems that arise in the Qur'an and the sunnah. If there is no clue from both of them, they do ijtihad by means of deliberation with the other superior authorities. This period is called the period of al-tafsir al-tashri', which is the pioneering period of the practice of istinbāt (excavation; formulation) of law on problems that do not have a clue in the text. ${ }^{20}$ This is what marked the beginning of the first fiqh period in the history of the development of Islamic legal thought.21

According to al-Sayis, fatwā șahāba has a broad meaning, namely their ijtihad activities which include searching for religious texts according to the problem, performing qiyās, istihsān, sadd al-dharī'a, mașlaḥa mursala, and so on. ${ }^{22}$ However, these terms did not appear at that time as the treasury of Islamic legal terms except during the time of the Imams of the school.

\section{Fatwā Sahāâba and its Prosperity in the Thought of Islamic Law}

Fatwa $\bar{a}$ Șhāba in the history of the development of Islamic legal thought is divided into two categories, first; the words of a șahāba that has been agreed upon and secondly; disputed words of șaḥāba.

a. If the words of șahāba was spread among the other șahāba and no one is known to deny it, then it can be used as evidence. The words of this type of șahāba are agreed upon ijmán' sukūtī can be used as hujjah. ${ }^{23}$

b. If the words of a șahāba come from his own opinion or ijtihad then this is a dispute about its validity to be used as evidence in Islamic legal thinking.

\footnotetext{
${ }^{19}$ Muḥammad Mūsā Tuwānā, Al-Ijtihād Wa Madā Hājātinā Ilayh Fì Hādhā Al-'Aṣr, 30.

20Strzyzewska, Tārīkh Al-Tashrī’ Al-Islāmī, 360.

${ }^{21}$ Aḥmad Ibrāhīm Bik, Tārīkh Al-Tashrī’ Al-Islāmī, 16.

${ }^{22} \mathrm{Al}$-Sāyis, Tārīkh Al-Fiqh Al-Islāmiyah, 43.

23`Abd al-Karīm Zaydan, Al-Wajīz Fì Ușūl Al-Fiqh (Beirut: Mu’assasah al-Risālah, 1996), 260-261.
} 
Muhammad Sulaiman Abdullah al-Asyqar added several points regarding the types of fatwās șahāba, those are:24

a. Al-Khulafā al-Rāshidīn's words in a problem. The scholars agreed to make it a hujjah as explained in the hadith of the Holy Prophet, "you should follow my sunnah and the sunnah of the alKhulafä' al-Rāshidīn after me".

b. The words of a companion who is based on his thoughts and is opposed by other sahāaba. Some scholars believe that such words of șahāba cannot be used as evidence. While other scholars from the ușūliyyin and jurists require to take it.

Based on the description above it is understood that the words of șahāba have several kinds of variations. All scholars agree that the words of a sahāba that is disputed as validity of hujjah are: (1) the words of a companion that comes from his own opinion and ijtihad; (2) the words of sahāba over problems that can be the object of ijtihad; (3) the words of șahāba that are not spread among the other șahāba and no șahāba who deny this opinion; (4) the words of the companions on a problem for which there are no texts, either the Qur'an or the hadith; and (5) the words of șhâaba who reach the next generation, such as tabi'in and continue to the present day.

As for the words of șahāaba who do not fall into the above categories, can be used as evidence in the taking of Islamic law. When there are differences of opinion regarding the validity of the fatwo of the Companions as a source of Islamic law, it can be understood that the fatwo of the Companions referred here is the fatwa of the companions that are still disputed regarding their validity. Because of this, not all the fatwās of șahāāba are disputed as validity.

\section{Some Ulema's Reasons in Accepting Fatwā Șahāāba as Hujjah}

Some scholars who argue that the fatwā of șahāba can be used as absolute hujjah and take precedence over the qiyās include Mālik and Ahmad.25 The legal basis are:

a. Qur'an Surah Āli 'Imrān (2) Verse 110

Meaning: "You are the best nation produced [as an example] for mankind. You enjoin what is right and forbid what is wrong and

\footnotetext{
${ }^{24} \mathrm{Al}-\mathrm{Asqar}, \mathrm{Al}$-Wādịh Fì Ușūl Al-Fiqh, 134-135.

25Mușțafā Al-Baghā, Āthār Adillah Al-Mukhtalaf Fīhā Fi Al-Fiquh Al-Islāmīi, 343-344.
} 
Hamid Pongoliu

believe in Allah. If only the People of the Scripture had believed, it would have been better for them. Among them are believers, but most of them are defiantly disobedient."

b. Qur'an Surah Yāsīn (36) Verse 15

Meaning: "They said, "You are not but human beings like us, and the Most Merciful has not revealed a thing. You are only telling lies."

c. The Prophet's hadith

The command of the Holy Prophet to always follow his companions and follow the sunnah of al-Khulafā al-Rāshidīn is a strong argument that the Companions of the Prophet must be obeyed. More than that, in a narration of the history of alTirmīdhī and Hudhayfah, clearly the Prophet ordered to follow Abū Bakr and 'Umar. Then in another narration, the Holy Prophet also said that the best generation after his time was the generation of șạ̄āba and tābi'īn.

d. Ijmā'

For example, when 'Abdurrahmān bin 'Awf became the head of the khalifa election committee after 'Umar, he first offered 'Alī to be a caliph on condition that he followed the sunnah of the two previous caliphs, but 'Alī refused. Then he offered 'Uthmān the same terms and 'Uthmān accepted it. At that time there was no companion who denied the proposed conditions so that they reached the degree of $i j m \bar{a}$ '.

e. Dalīl 'Aqlī

The methods of $\operatorname{sim}^{-}{ }^{\prime} \bar{l}$ and tawkîf of the companions are very strong and it is customarily impossible for them to obey except based on the history they have heard. In addition, they will not claim based on their opinion except in an emergency. Meanwhile, the words of șahāba although originating from ijtihad but it can be ascertained their ijtihad is strong. This is because they know the process of the descent of the Qur'an and the methods that the Prophet used to convey and explain various laws in a matter.

\section{The Reason Some Scholars Refuse the Fatwā Șahāāba as Hujjah}


Some scholars who reject the fatwā of șahāba as a hujjah include alGhazālī, the majority of al-Ash'aria, Mu'tazilah and so on. The propositions they use are:

a. Qur'an Surah al-Ḥashr (59) Verse 2

Meaning: "...So take warning, 0 people of vision."

The verse commands humans to ijtihad. Whereas ijtihad is different from imitation. If ijtihad is an attempt to find proof in a problem, then taqlïd is to take another opinion without an argument. Taking fatwo thus falls into the category of imitation. This is certainly contrary to the word of Allah in Surah al-Nisā' (4) Verse 59 as follows.

Meaning: "O you who have believed, obey Allah and obey the Messenger and those in authority among you. And if you disagree over anything, refer it to Allah and the Messenger, if you should believe in Allah and the Last Day. That is the best [way] and best in result."

Fatwa șaḥāba is one of the products of ijtihad. While their ijtihad can be right or wrong, because they are not ma'șūm (awake from making mistakes). On the contrary, the șahāba have agreed that their ijtihad may be challenged if it is not appropriate. As Abū Bakr and 'Umar did not blame those who refused their ijtihad. However, it is obligatory for all mujtahids to do jihad on issues that are included in the object of ijtihad.

b. Al-Shāfi'i's opinion of Companions fatwa $\bar{a}^{26}$

Al-Shāfi'i explained in detail about this. He makes the fatwā of șahāba as hujjah if the șahāba agree on a problem that is not argued in the Qur'an or hadith and there are no șahāba who reject that opinion. In this situation, the fatwo of șahāba takes precedence over qiyās because it is included in the ijmak category. For example, the obligation to slaughter one sheep for those who hunt doves in a state of Ihram. This follows the deeds of the sahāba who slaughter the sheep for anyone who hunts in the state of ihrām.

If there is a difference of opinion among the sahāba on a problem, then the opinion is taken closer to the Qur'an, hadith,

26Jum’ah, Qawl Al-Ṣaḥābī înda Ușūliyyīn, 40. 
ijmā' and qiyās or opinions supported by other propositions. For example, al-Shāfi'î took the fatwā of șahāba in determining when the last talbiyah was echoed during the 'umrah or the words of 'Umar in khiyār disgrace in marriage or the words of 'Ali in the law of the woman who was left by the missing husband. If the fatwa of sahāba does not agree and no one violates, then alShāfi'i puts the qiyās before the fatwā of that companion. AlShāfi'î further makes the fatwās of șahāba as an explanation in understanding the Qur'an and hadith. Like the explanation of sahāa ba about the meaning of al-jazā' in Surah al-Mā'idah (5) Verse 95, the obligation of zakat on the property of small children and crazy people and so on. ${ }^{27}$ The difference of opinion of the scholars regarding the position of the fatwa of șahāba as one of the sources of tashri' also causes a difference in punishing a problem that no texts explain.

\section{Conclusion}

Qawl al-Șahāba has a strong influence on the development of Islamic legal thought, then until now. When Muslims discover new problems, the fatwa of the Companions can be used as a solution to the legal support of Islamic law. The influence of $r a^{\prime} y$ which was done by sahăba in devotion, has inspired the thoughts of Muslims until now. The ra'y is here of course with a broad understanding that includes qiyās, istihsān, istișhāb (al-barā'a al-aṣliya), sadd aldhari'ah and mașlahah mursalah. Everything is framed with a deep understanding of the maqāsid (the purpose of Islamic law) and the principles of the noble Islamic law. The scholars categorize qawl al-sahăbi as one source of legal decision which is still being disputed. In contrast to Qur'an, sunnah, $i j m \bar{a}$ and qiyās that have been agreed upon as sources of Islamic law.[a]

\section{BIBLIOGRAPHY}

Al-'Azīz, 'Abd. 'Al-Ṣahābī'. In Al-Mawsū'ah Al-Islāmiyah Al-'Ammah. Kairo: Majlis A'lā, 2003.

27Mușțafā Al-Baghā, Āthār Adillah Al-Mukhtalaf Fīhā Fi Al-Fiqh Al-Islāmī, 110-122. 
Al-Āmidī, 'Alī Ibn-Abī ‘Alī. Al-Iḥkām Fī Uṣūl Al-Aḥkām. II. Beirut: Dār al-Kitāb al'Arabī, 1984.

Al-Asqar, M. Sulaymān 'Abdullāh. Al-Wāḍiḥ Fĩ Ușūl Al-Fiqh. Dār al-Nafā’is, 2001.

Al-Baghā, Muștafā. Āthār Adillah Al-Mukhtalaf Fīhā Fi Al-Fiqh Al-Islāmī. Dār-alQalam, 1999.

Al-Bukhārī, Muhammad Ibn Ismāīl. Șahịḥ Al-Bukhārī. III. Beirut: Dār al-Ṣa'b, n.d.

Al-Sāyis, Muhammad 'Alī. Tārīkh Al-Fiqh Al-Islāmiyah. Beirut: Dār al-Kutub al'Ilmiyah, 1990.

Al-Suyūțī, Jalāl al-Dīn 'Abd al-Rahmmān. Al-Radd 'alā Man Akhlad Ilā Al-Arḍ Wa Jahila Ann Al-Ijtihād Fi Kulli 'Așr Farḍ. Beirut: Dār al-Kutub al-'Ilmiyah, 1983.

Bik, Aḥmad Ibrāhīm. Tārīkh Al-Tashrī' Al-Islāmī. Kairo: Dār al-Anșār, n.d.

Effendi, Satria. Ushul Fiqh. Edited by M. Nurul Irfan Aminuddin Ya'kub. Jakarta: Kencana Prenada Media Group, 2008.

Faḍlullāh, Madhịi. Al-Ijtihād Wa Al-Manțiq Al-Fiqh Fī Al-Islām. Beirut: Dār alTalī'ah, 1987.

Juddah, Nurdin. 'Metode Ijtihad Hakim Dalam Penyelesaian Perkaran: Studi Kasus Di Pengadilan Tinggi Agama Makassar Sulawesi Selatan'. UIN Alauddin Makasar, 2010.

Jum'ah, 'Alī. Qawl Al-Ṣaḥābī 'inda Ușūliyyīn. Kairo: Dār al-Risālah, 2004.

Khairul Umam, HLM. A. Achyar Aminudin. Ushul Fiqh II. Bandung: Pustaka Setia, 1989.

Khalil, Rasyad Hasan. Tarikh Tasyri': Sejarah Lagalisasi Hukum Islam. Edited by Nadirsyah Hawari. Amzah, 2009.

Mubarok, Jaih. Sejarah dan Perkembangan Hukun Islam. Bandung: Remaja Rosda Karya, n.d.

Strzyzewska, Bozena Gajane. Tārīkh Al-Tashrī’ Al-Islāmī. Beirut: Dār al-Awqāf al-Jadīdah, 1980.

Tuwānā, Muhammad Mūsā. Al-Ijtihād Wa Madā Hājātinā Ilayh Fī Hādhā Al-'Așr. Kairo: Dār al-Kutub al-Hadìthah, n.d.

Zaydan, 'Abd al-Karīm. Al-Wajīz Fì Ușūl Al-Fiqqh. Beirut: Mu'assasah al-Risālah, 1996. 
Hamid Pongoliu

Zuhri, Muhammad. Hukum Islam dalam Lintasan Sejarah. Jakarta: Remaja Rosda Karya, 1996. 